\title{
EVALUATION OF CYTOTOXIC AND GENOTOXIC EFFECTS OF ZERUMBONE ON COLON ADENOCARCINOMA COLO205 CELLS AND HUMAN LYMPHOCYTES
}

\author{
RIMA THIYAM*a, MANGAMOORI LAKSHMI NARASU ${ }^{b}$ \\ a,bCentre for Biotechnology, Institute of Science and Technology, Jawaharlal Nehru Technological University Hyderabad, Kukatpally, \\ Hyderabad 500085, Telangana, India \\ Email: rimaroseth@yahoo.com
}

Received: 04 Jul 2017 Revised and Accepted: 21 Sep 2017

\begin{abstract}
Objective: The objective of the present study was to investigate the growth inhibitory effect, apoptosis initiation and genotoxicactivity of zerumbone, a phytochemical and cisplatin, a chemotherapeutic drugon human colorectal cancer cell line COLO205 and normal human lymphocytes.

Methods: The antiproliferative activity of zerumbone and cisplatin (positive control) on COLO205cells and lymphocytes was analysed by 3-(4,5dimethylthiazol-2-yl)-2,5-diphenyltetrazolium bromide (MTT) assay. Morphological analysis of the cells was studied by using an inverted phase contrast microscope. Propidium iodide staining method was used to observe the apoptotic morphological changes in the treated cells. Finally, comet assay was conducted to observe the extent of DNA damage induced by zerumbone and cisplatin on COLO205 and lymphocytes.

Results: Zerumboneand cisplatin exhibited growth inhibition in a doseand time-dependent manner against COLO205 with not much considerable effect on lymphocytes. The IC 50 values of zerumboneand cisplatinon COLO205 for $24 \mathrm{~h}, 48 \mathrm{~h}$ and $72 \mathrm{~h}$ were $19 \mu \mathrm{g} / \mathrm{ml}, 10 \mu \mathrm{g} / \mathrm{ml}, 5 \mu \mathrm{g} / \mathrm{ml} \mathrm{and} 38 \mu \mathrm{g} / \mathrm{ml}, 24 \mu \mathrm{g} / \mathrm{ml}, 15$ $\mu \mathrm{g} / \mathrm{ml}$. Morphological changes such as cell shrinkage, membraneblebbing and nuclear condensation were observedin COLO205 whilea more prominent change was notobserved in lymphocytes. Fluorescence imaging studies confirmed apoptotic cell death in treated COLO205 cells while cell death was not clearly observed in treated lymphocytes. Comet assay revealed asignificant DNA damage in treated COLO205 cells.
\end{abstract}

Conclusion: The present study demonstrated the cytotoxic and genotoxic effects of zerumboneon colon cancer cells with minimal effect on normal lymphocytes. The results of the study have revealed that zerumbone can be used as an effective therapeutic drug in treating colon cancer.

Keywords: Zerumbone, Cisplatin, COLO205, Lymphocytes, MTT assay, Comet assay

(C) 2017 The Authors. Published by Innovare Academic Sciences Pvt Ltd. This is an open access article under the CC BY license (http://creativecommons.org/licenses/by/4.0/) DOI: http://dx.doi.org/10.22159/ijpps.2017v9i11.21120

\section{INTRODUCTION}

Plant-derivedcompounds are most commonly used as medicines in the world today. Every culture on Earth, through written or oral tradition, has relied on the huge variety of natural products found in healing plants for their curative properties. One-fourth of modern drugs prescribed worldwide are plant-derived, where 121 of these bioactive compounds are currently used in the treatment of various ailments [1]. Natural phytochemicals hold a great promise in clinical therapy as they possess no side effects that are usually associated with chemotherapy or radiotherapy. They are also comparatively inexpensive as they are ubiquitousand thus significantly reduce health care cost. Phytochemicals are the plant compounds with specific biological activities that support human health [2].

Zerumbone is a phytochemical, present in the rhizomes of Zingiberzerumbet Smith and Zingiberaromaticum [3]. Its molecular formula is $\mathrm{C}_{15} \mathrm{H}_{22} \mathrm{O}$.The IUPAC name of this phytochemical is $(2 \mathrm{E}, 6 \mathrm{E}$, 10E)-2, 6, 9, 9-tetramethyl cycloundeca-2, 6, 10-trien-1-one [4]. It was found to possess many biomedical properties such as antioxidant, anti-inflammatory and antimicrobial activities [5,6]. It has been proven to possess anti-cancer, immunomodulatory and apoptosis-inducing properties against various human tumour cells, but with least effect on normal cells [7-11].

A variety of in vitro genotoxicity test systems have been developed in the cultured mammalian cell systems such as human peripheral blood lymphocytes for the screening of potentially cytotoxic, mutagenic and carcinogenic agents [12-14].According to the literature survey, there exists a lack of good basic information about the genotoxic potential of zerumbone on colon cancer cells. In this context, the present work has been carried out to study the genotoxic potential of zerumbone on human colorectal cancer cell line, COLO205 and human peripheral blood lymphocytes. The current work can be seen as the comparative analysis of zerumbonegenotoxicactivity against the COLO205 cells and lymphocytes, as well the cell growth inhibition and apoptosis induction by zerumbonein COLO205 cells and lymphocytes were studied.

\section{MATERIALS AND METHODS}

\section{Chemicals}

Zerumbone, cisplatin, lymphocyte isolation medium (Histopaque 1077), MTT and propidium iodide were purchased from Sigma Aldrich (St. Louis, MO, USA). Fetal bovine serum, RPMI 1640, trypsin and dimethyl sulfoxide (DMSO) were procured from $\mathrm{Hi}$ media (Mumbai, India). All other chemicals and reagents used in this study were of analytical or HPLC grade and obtained from Sigma Aldrich (St. Louis, MO, USA) and Himedia (Mumbai, India).

\section{Cell culture and maintenance}

Human colorectal cancer cell line, COLO205 was obtained from National Centre for Cell Science, Pune (India). Cells were cultured in RPMI 1640 supplemented with 10\%fetal bovine serum, penicillin $(100 \mathrm{IU} / \mathrm{ml})$ and streptomycin $(100 \mu \mathrm{g} / \mathrm{ml})$ at $37^{\circ} \mathrm{C}$ in a humidified incubator with $5 \% \mathrm{CO}_{2}$ atmosphere. Once the cells reached $\sim 90 \%$ confluency, they were trypsinized, washed thoroughly with media and subcultured into a new $25 \mathrm{~cm}^{2}$ culture flask for expansion.

\section{Isolation of peripheral blood lymphocytes}

Peripheral blood was aseptically collected from healthy, nonsmoking donors (below $30 \mathrm{y}$ ) by venepuncture into preservativefree EDTA tubes. The blood was diluted by adding phosphate buffered saline (PBS), pH 7.4 and carefully layered onto Histopaque 1077, centrifuged at $400 \mathrm{x}$ g for $30 \mathrm{~min}$, at interface lymphocytes were suspended. Trypan blue exclusion was used to assess the viability of isolated lymphocytes and the viability of these cells was found to be above $90 \%$. The final concentration of lymphocytes was adjusted to about $2 \times 10^{5}$ cells $/ \mathrm{ml}$. 


\section{Anti-proliferative activity of zerumbone and cisplatin}

TheMTT assay was performed to study the antiproliferative effect of zerumbone and cisplatin on COLO205 and lymphocytes. Cells were treated with varying concentrations $(0-100 \mu \mathrm{g} / \mathrm{ml})$ of zerumbone and cisplatin for different time intervals $(24 \mathrm{~h}, 48 \mathrm{~h}, 72 \mathrm{~h})$ at $37{ }^{\circ} \mathrm{C}, 5 \%$ $\mathrm{CO}_{2}$ along with the untreated control samples (which contained an equivalent concentration of DMSO). After every incubation period, cells were washed with PBS, treated with MTT and again incubated for $4 \mathrm{~h}$ after which MTT was removed, then DMSO was added and finally, the plate was read at $540 \mathrm{~nm}$ in an ELISA plate reader. The data were represented as the percent post-treatment recovery (\% live cells), whereas the absorbance from untreated control cells was defined as $100 \%$ live cells.

\section{Morphological studies using normal inverted microscope}

Treated cells were observed under anormal inverted microscope following $24 \mathrm{~h}, 48 \mathrm{~h}$ and $72 \mathrm{~h}$ of incubation. The changes in cellular morphology due to death were examined and compared with untreated control. Photomicrographs were taken under the inverted microscope at $100 \times$ magnification.

\section{Propidiumiodide staining}

Propidium iodide fluorescence staining method was used to observe the apoptotic morphological changes in the treated cells. Both COLO205 cells and lymphocytes were treated with $\mathrm{IC}_{50}$ concentrations of zerumbone and cisplatin for $24 \mathrm{~h}$. The untreated cells served as control. After incubation, cells were washed with PBS, fixed in absolute alcohol for $30 \mathrm{~min}$ at $4^{\circ} \mathrm{C}$, rehydrated with PBS and incubated with $100 \mu$ lpropidium iodide $(25 \mu \mathrm{M})$ at $37^{\circ} \mathrm{C}$ for $5 \mathrm{~min}$. Photomicrographs were taken under a fluorescent microscope at $200 \mathrm{x}$ magnification.

\section{Comet assay}

DNA damage was assessed using the comet assay according to the method of Tice et al. [15].10 $\mu \mathrm{l}$ of the treated and untreated cells were suspended in $70 \mu \mathrm{l}$ of $1 \%$ low melting agarose in PBS and were layered onto the slides pre-coated with $1 \%$ normal melting agarose. The slides were incubated at $4{ }^{\circ} \mathrm{C}$ for $30 \mathrm{~min}$. A third layer was coated with $1 \%$ normal melting agarose and the slides were kept to dry. After solidification, the slides were kept in cold lysis buffer (10mmol Tris, $2.5 \mathrm{M} \mathrm{NaCl}, 100 \mathrm{mmol}$ EDTA, 1\% N-lauroylsarcosine; $\mathrm{pH} 10$ ) with fresh $1 \%$ Triton X-100 and $10 \%$ DMSO overnight at $4{ }^{\circ} \mathrm{C}$. For unwinding of the DNA, the slides were incubated in freshly prepared alkaline electrophoresis buffer $(300 \mathrm{mmol} \mathrm{NaOH}, 1 \mathrm{mmol}$ EDTA; pH 13) for $20 \mathrm{~min}$. The DNA was electrophoresed at $25 \mathrm{~V}$ and $300 \mathrm{~mA}$ for $20 \mathrm{~min}$ at $4{ }^{\circ} \mathrm{C}$. After electrophoresis, the slides were washed thrice with a neutralizing buffer (0.4 M Tris-HCl; $\mathrm{pH} 7.5$ ), left to dry for $30 \mathrm{~min}$ and fixed in75\% ethanol for $10 \mathrm{~min}$. After staining with $25 \mu \mathrm{M}$ propidium iodide, comets from individual cells were examined using a fluorescence microscope. OPEN COMET software was used to score 50 comets for each experiment.

\section{Statistical analysis}

Values were expressed as the mean \pm standard deviation (SD), where $\mathrm{n}=5$ for the MTT assay and $\mathrm{n}=3$ for the comet assay. The values were subjected to analysis of variance (ANOVA)using GraphPad Prism software, Version 6.01(California, USA).A statistically significant difference was considered to be present at $P<0.05$.

\section{RESULTS AND DISCUSSION}

\section{Effect of zerumbone and cisplatin on cell growth}

The antiproliferative effect of zerumbone and cisplatin on colorectal cancer cell line, COLO205 and normal human lymphocytes was determined by MTT assay. The growth of the cancer cells was inhibited in a dose $(0-100 \mu \mathrm{g} / \mathrm{ml})$ and time $(24 \mathrm{~h}, 48 \mathrm{~h}, 72 \mathrm{~h})$ dependent manner after exposure to zerumbone and cisplatin whereas lymphocytes were not affected after the exposure (fig.1).Previous studies reported the growth inhibition property of zerumboneon human colonic adenocarcinoma cell lines in a dosedependent manner, while the growth of normal human dermal and colon fibroblast was minimally affected [16]. Our studies exhibited that zerumbone can induce acytotoxic effect on colon cancer cells in a dose as well astime-dependent manner.
The $\mathrm{IC}_{50}$ values of zerumbone and cisplatin on COLO205 cells for different incubation periods $(24 \mathrm{~h}, 48 \mathrm{~h}$ and $72 \mathrm{~h})$ were found to be 19 $\mu \mathrm{g} / \mathrm{ml}, 10 \mu \mathrm{g} / \mathrm{ml}, 5 \mu \mathrm{g} / \mathrm{ml}$ and $38 \mu \mathrm{g} / \mathrm{ml}, 24 \mu \mathrm{g} / \mathrm{ml}, 15 \mu \mathrm{g} / \mathrm{ml}$ respectively (table 1). The IC $\mathrm{I}_{50}$ concentrations were considered for further studies. Zerumbone, anatural dietary compound found in the rhizome of Zingiberzerumbet, exerts anticancer activity against various cancers, both in vivo and in vitro [17].Literature stated that zerumbone hits a redox-regulated mechanismto selectively suppress the proliferation of cancer cells [18]. The cytotoxic activity of zerumbone on cancer cells is said to be attributed by the presence of $\alpha, \beta$-unsaturated carbonyl group in its structure, which plays a major role in interaction with the most biologically active molecules. According toMurakami et al., zerumbone displayed a selective cytotoxic characteristic towards cancer cell lines and normal cell lines [3].The results of our cytotoxic studies have also proved that zerumbone can induce cytotoxic effect selectively on colon cancer cells but not on the normal lymphocytes.
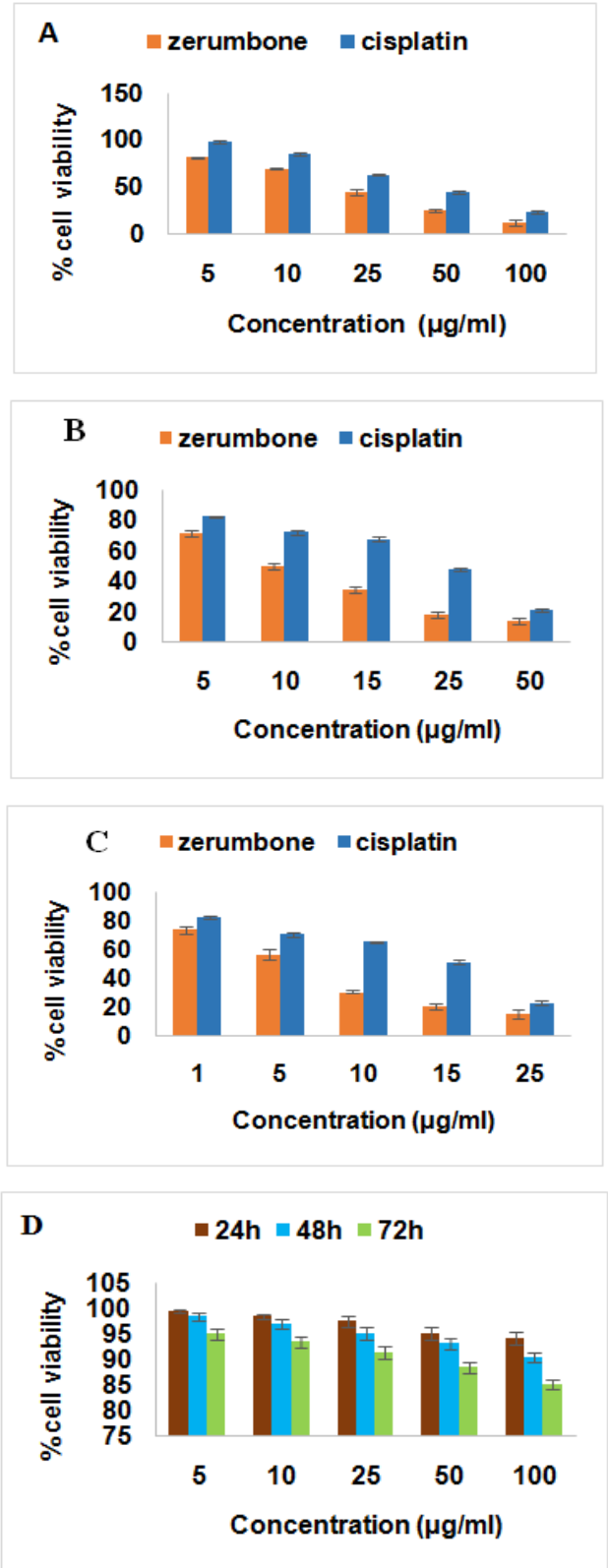

Fig. 1: Cytotoxic activity of zerumbone and cisplatin on COLO205 and lymphocytes as determined by MTT assay, COL0205cells were treated with zerumbone and cisplatin for (A) $24 \mathrm{~h}$, (B) $48 \mathrm{~h}$ and (C) $72 \mathrm{~h}$. Lymphocytes treated with zerumbone for $24 \mathrm{~h}, 48 \mathrm{~h}$ and $72 \mathrm{~h}$ is shown in (D). Values are expressed as mean $\pm S D(N=5)$ percentage cell viability 
Table 1: IC 50 values of zerumbone and cisplatin on COLO205 cells for $24 \mathrm{~h}, 48 \mathrm{~h}$ and $72 \mathrm{~h}$

\begin{tabular}{llll}
\hline Compound & $\mathbf{I C}_{\mathbf{5 0}}(\boldsymbol{\mu g} / \mathbf{m l})$ & & \\
\cline { 2 - 4 } & $\mathbf{2 4} \mathbf{h}$ & $\mathbf{4 8 ~ h}$ & \\
\hline Zerumbone & 19 & 10 & $\mathbf{7 2} \mathbf{h}$ \\
Cisplatin & 38 & 24 & 5 \\
\hline
\end{tabular}

\section{Effect of zerumboneand cisplatin on apoptotic cell death}

COLO205 cells and lymphocytes were exposed toIC ${ }_{50}$ concentrations of zerumbone and cisplatin. The treated cancer cells demonstrated early signs of apoptosis such as membrane blebbing and cytoplasmic shrinkage (fig.2).The untreated COLO205 cells and treated lymphocytes showed a negligible change in the membrane morphology (fig. 2,3).In the present study, it is proposed that zerumboneinhibits the cell proliferation by subsequent induction of apoptotic cell death of the colon cancer cells. This is clearly evident by the morphological changes in zerumbonetreated COLO205 cells that include distinctive nuclear morphology, chromatin condensation and fragmentation, loss of cell volume and production of apoptotic bodies (fig.4), which are all features of apoptosis [19].Several studies have exposed the apoptotic nature of zerumboneagainst various cancer cells, but it has anegligible effect on normal cells [3].
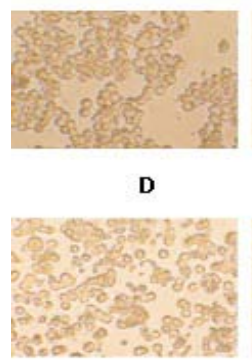

$\mathbf{G}$

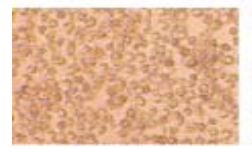

B

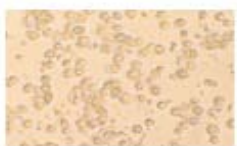

E

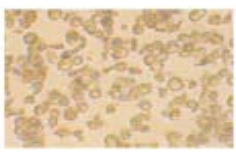

H

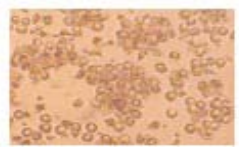

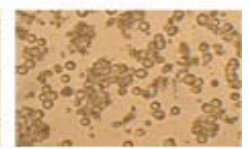
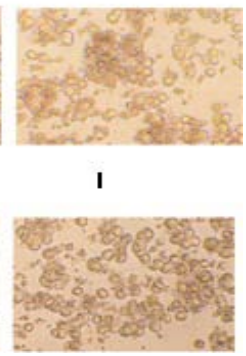

Fig.2: Effect of zerumbone and cisplatin on COLO205.Cells were treated for $24 \mathrm{~h}$ : (A) control, (B) $19 \mu \mathrm{g} / \mathrm{mlzerumbone}$, (C)

$38 \mu \mathrm{g} / \mathrm{mlcisplatin}$; for $48 \mathrm{~h}$ : (D) control, (E) $10 \mu \mathrm{g} / \mathrm{mlzerumbone}$,

(F) $24 \mu \mathrm{g} / \mathrm{mlcisplatin}$ and for $72 \mathrm{~h}$ : (G) control, (H)

$5 \mu \mathrm{g} / \mathrm{mlzerumbone}$ (I) $15 \mu \mathrm{g} / \mathrm{mlcisplatin}$
A

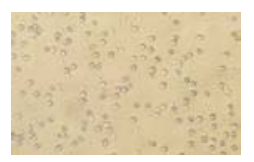

D

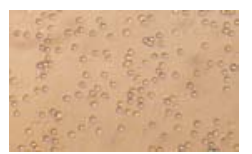

G

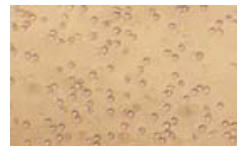

B

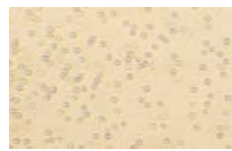

E

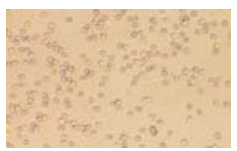

H

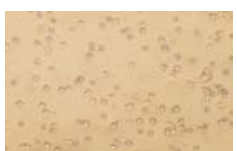

C

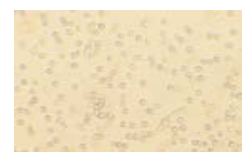

F

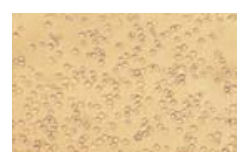

I

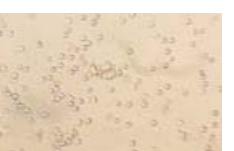

Fig.3: Effect of zerumboneand cisplatinon lymphocytes. Cells were treated for $24 \mathrm{~h}$ : (A) control, (B) $19 \mu \mathrm{g} / \mathrm{mlzerumbone}$, (C) $38 \mu \mathrm{g} / \mathrm{mlcisplatin}$; for $48 \mathrm{~h}$ : (D) control, (E) $10 \mu \mathrm{g} / \mathrm{mlzerumbone}$,

(F) $24 \mu \mathrm{g} / \mathrm{mlcisplatin}$ and for $72 \mathrm{~h}$ : (G) control,(H) 5 $\mu \mathrm{g} / \mathrm{mlzerumbone}$ (I) $15 \mu \mathrm{g} /$ mlcisplatin
A

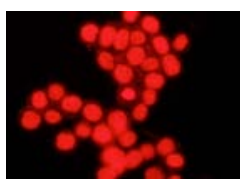

D

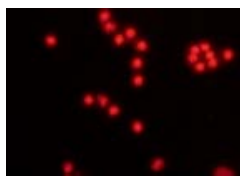

B

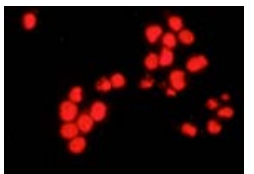

E

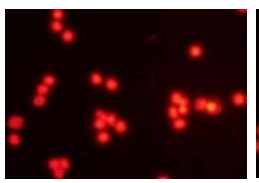

C

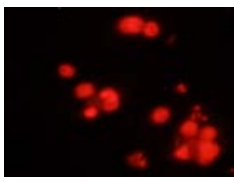

$\mathbf{F}$

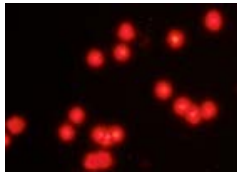

Fig.4: Morphological alterations of COLO205 and lymphocytes treated with zerumboneand cisplatin (A) untreated COLO205,

(B) COLO205 treated with zerumbone $(19 \mu \mathrm{g} / \mathrm{ml})$, (C) COLO205 treated with cisplatin $(38 \mu \mathrm{g} / \mathrm{ml})$, (D) untreated lymphocytes,

(E) lymphocytes treated with zerumbone $(19 \mu \mathrm{g} / \mathrm{ml})$ and (F) lymphocytes treated with cisplatin $(38 \mu \mathrm{g} / \mathrm{ml})$

A

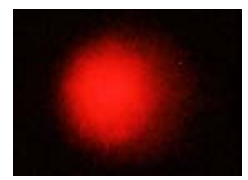

D

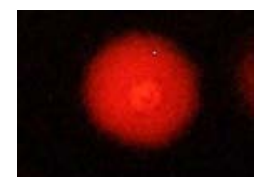

B

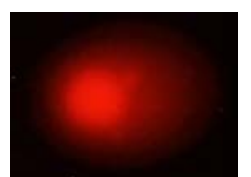

$\mathbf{E}$

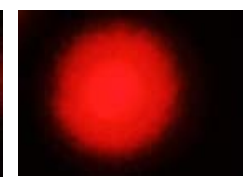

C

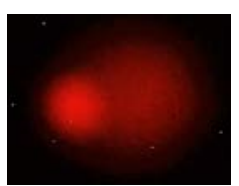

$\mathbf{F}$

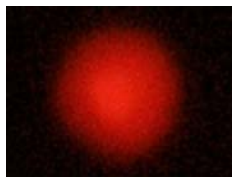

Fig.5: Genotoxic effect of zerumbone and cisplatin on COLO205 cells and lymphocytes, (A) untreated COLO205, (B) COLO205 treated with zerumbone $(19 \mu \mathrm{g} / \mathrm{ml}),(C)$ COLO205 treated with cisplatin (38 $\mu \mathrm{g} / \mathrm{ml})$, (D) untreated lymphocytes, (E) lymphocytes treated with zerumbone $(19 \mu \mathrm{g} / \mathrm{ml})$ and $(F)$ lymphocytes treated with cisplatin $(38 \mu \mathrm{g} / \mathrm{ml})$

Genotoxic effect of zerumbone and cisplatin on cancer cells and lymphocytes

Comet assay is a simple, rapid and reliable technique for the detection and quantification of DNA damage.The assay determines the extent of DNA damage in individual cells and this can be assessed from the length of DNA migration [15].Comet assay was performed to analyse the extent of DNA damage caused by zerumbone and cisplatinon cancer cells and normal human lymphocytes. The tail length, \% tail DNA and olive moment are considered as DNA damage parameters [20].The zerumbone treated COLO205 cells showed a significant DNA damage with the tail length of85.61, percentage DNA in tail of 27.42and olive moment of 25.14 when compared to the untreated control cells. The cisplatin treated COLO205 cells also showed a significant DNA damage with the tail length of 69.36, percentage DNA in tail of 22.27 and olive moment of 18.38when compared to the untreated control cells. In contrast, the treated lymphocytes did not demonstrate any obvious DNA damage when compared to the untreated lymphocytes. The zerumbonetreated lymphocytes illustrated tail length of 7.23, percentage DNA in tail of 6.88and olive moment of 1.64. And the 
cisplatin-treatedlymphocytes illustratedtail length of 6.91, percentage DNA in tail of 6.23and olive moment of 1.46 (fig.5; table 2).The genotoxic agents have the ability to interact with DNA and cause DNA damage.Our findings illustrated that zerumbonecan cause DNA damage on colon cancer cells. Previous studies have evaluated the genotoxic effect of zerumbone as dose-dependent on chinese hamster ovary cells and human peripheral blood lymphocytes. It has also reported that zerumbone is a cytotoxic but not a clastogenic substance in human lymphocytes [21,22]. Zerumbone carried no obvious structural alerts and no particular mechanism had been identified such as nucleoside analogues that can cause genotoxic effect, making it necessary for further studies to better understand the molecular mechanisms of action of zerumbone. The present results provide an additional evidence that zerumbone has a genotoxic and cytotoxic effects on colorectal cancer cells, while subsidized effects were observed onhuman lymphocytes.

Table 2: Effect of zerumbone and cisplatin on the extent of DNA damage on COLO205 and lymphocytes

\begin{tabular}{llll}
\hline Concentration & DNA damage & Olive moment \\
\cline { 2 - 4 } & Tail length & \% Tail DNA & $5.77 \pm 0.11$ \\
\hline COLO205 & $20.95 \pm 0.17$ & $15.97 \pm 2.47$ & $25.14 \pm 1.23$ \\
Untreated Control & $85.61 \pm 1.86$ & $27.42 \pm 0.63$ & $18.38 \pm 1.31$ \\
Zerumbone $(19 \mu \mathrm{g} / \mathrm{ml})$ & $69.36 \pm 1.35$ & $22.27 \pm 0.26$ & \\
Cisplatin $(38 \mu \mathrm{g} / \mathrm{ml})$ & & & $0.57 \pm 0.04$ \\
Lymphocytes & $1.77 \pm 0.17$ & $1.94 \pm 0.11$ & $1.64 \pm 0.21$ \\
Untreated Control & $7.23 \pm 0.65$ & $6.88 \pm 0.46$ & $1.46 \pm 0.11$ \\
Zerumbone $(19 \mu \mathrm{g} / \mathrm{ml})$ & $6.91 \pm 0.21$ & $6.23 \pm 0.11$ & \\
Cisplatin $(38 \mu \mathrm{g} / \mathrm{ml})$ & & \\
\hline
\end{tabular}

The values are expressed in mean $\pm \mathrm{SD}, \mathrm{n}=3, P<0.0001$

\section{CONCLUSION}

In the present study, zerumbone and cisplatin exhibited a potent antiproliferative activity against cancer cells, but with negligible effect on normal lymphocytes. Fluorescent microscopic and genotoxic studies have revealed that zerumboneis a strong inducer of apoptosis and caused DNA damage in the cancer cells but with minor effect on lymphocytes. These findings have demonstrated that zerumbone can be a potential phytochemical to treat colon cancer. Further studies have to be carried out in animal models and clinical trials have to be conducted.

\section{ACKNOWLEDGEMENT}

Rima Thiyam acknowledges financial support from DST Inspire Division, Department of Science and Technology, New Delhi, India in the form of DST Inspire Fellowship (IF120002, Grant No. DST/INSPIRE Fellowship/2012/70) to the present research work. The authors are grateful to Centre for Biotechnology, IST, JNTUH, Hyderabad for providing the laboratory facilities.

\section{AUTHORS CONTRIBUTION}

The study was designed by RT and MLN, as the supervisor provided conceptual and technical guidance for all aspects of the project. RT performed the experimental work and assessed the data. The manuscript was prepared by RT and its critical revision was done by MLN. Final approval of the manuscript was made by RT and MLN.

\section{CONFLICT OF INTERESTS}

There is not any conflict of interest which should be disclosed.

\section{REFERENCES}

1. Rates SMK. Plants as source of drugs. Toxicon2011;39:603-13.

2. Charu G,Prakash D. Phytonutrients as therapeutic agents. J Complementary Integr Med 2014;11:151-69.

3. Murakami A, Takahashi D, Kinoshita T, Koshimizu K, Kim HW, Yoshihiro A,et al.Zerumbone, a Southeast Asian ginger sesquiterpene, markedly suppress free radical generation, proinflammatory protein production, and cancer cell proliferation accompanied by apoptosis: the $\alpha$, the $\beta$-unsaturated carbonyl group is a prerequisite.Carcinogenesis2002;23:795-802.

4. Kitayama T, Okamoto T, Hill RK, Kawai Y, Takahashi S, Yonemori S,et al. Chemistry ofzerumbone. 1. simplified isolation, conjugate addition reactions, and a unique ring contracting transannular reaction of its dibromide. J Org Chem 1999;64:2667-72.

5. Zakaria ZA, Mohamad AS, Chear CT, Wong YY, Israf DA, Sulaiman MR. Anti-inflammatory and ant nociceptive activities of Zingiberzerumbetmethanol extract in experimental model systems.Med PrincPract2010;19:287-94.

6. Habsah M, Amran M, Mackeen MM, Lajis NH, kikuzaki H, NakatanI $\mathrm{N}$,et al.Screening of Zingiberaceae extracts for antimicrobial and antioxidant activities. J Ethnopharmacol2000;72:403-10.

7. Chandra K, Graeme HM, Ian RR, Graham PJ. Antitumor activity of anextract of Zingiberaromaticum and its bioactive sesquiterpenoidZerumbone. Nutr Cancer 2003;45:218-25.

8. Swagatika D, Monalisa R, Abtar M, Sajad S, Gopinath AK, Sanghamitra $\mathrm{N}$, et al.Zerumbone, a natural plant dietary compound induces expression of interleukin-12P70 cytokine in human peripheral blood mononuclear cells. Asian J Pharm Clin Res 2016;9Suppl3:312-5.

9. Sharifah Sakinah SA, Handayani ST,Azimahtol Hawariah LP.Zerumbone induced apoptosis in liver cancer cells via modulation of Bax/Bcl-2 ratio. Cancer Cell Int 2007;7:4.

10. Supachai Y, Bokyung S, Pornngarm L, Bharat B. Zerumbone enhances TRAIL-induced apoptosis through the induction of death receptors in human colon cancer cells: evidence for an essential role of reactive oxygen species. Cancer Res2009;69:6581-9.

11. Rahman HS, Rasedee A, How CW, Abdul AB, Zeenathul NA, Othman $\mathrm{HH}$, et al.Zerumbone-loaded nanostructured lipid carriers: preparation, characterization, and antileukemic effect. Int J Nanomed 2013;8:2769-81.

12. Celik M, Unal F, Yuzbasioglu D, Ergun MA, Arslan O, Kasap R. In vitro effect of karathane LC (dinocap) on human lymphocytes. Mutagenesis2005;20:101-4.

13. Duthei SJ, Perie L, JenkinsonAMcE, Narayanan S. Cryopreserved versus freshly isolated lymphocytes in human biomonitoring: endogenous and induced DNA damage, antioxidant status and repair capability. Mutagenesis 2002;17:211-4.

14. Houda S, Hayat T, Ibtissam T, Souad A, Abderraouf $H$. Evaluation of the genotoxicity of essential oil from Origanumcompactum Benth. in human lymphocytes. Asian J Pharm Clin Res 2016;9Suppl2:274-6.

15. Tice RR, Agurell E, Anderson D, Burlinson B, Hartmann A, Kobayashi $\mathrm{H}$,et al.Single-cell gel/comet assay: guidelines for in vitro and in vivo genetic toxicology testing. Environ Mol Mutagen2000;35:206-21.

16. Murakami A, Tanaka T, Lee JY, Surh YJ, Kim HW, Kawabata K, et al. ZER, a sesquiterpene in subtropical ginger, suppresses skin tumor initiation and promotion stages in ICR mice. Int J Cancer 2004; 110:481-90.

17. Shukla Y, Singh M. Cancer preventive properties of ginger: a brief review. Food ChemToxicol2007;45:683-90. 
18. Hoffman A, Spetner LM, Burke M. Redox-regulated mechanism may account for zerumbone's ability to suppress cancer-cell proliferation. Carcinogenesis 2002;23:1961.

19. O'Brien MA, Kirby R. Apoptosis: a review of pro-apoptotic and anti-apoptotic pathways and dysregulation in disease. J Vet EmergCrit Care 2008;18:572-85.

20. Singh RK, Mishra SK, Kumar N, Singh AK. Assessment of DNA damage by comet assay in lymphocytes of workers occupationally exposed to petroleum fumes. Int J Genet2010;2:18-22.

21. Adel SA, Ahmad BA, Syam MM. Evaluation of the genotoxicity of zerumbone in cultured human peripheral blood lymphocytes. ToxicolIn Vitro2010;24:707-12.

22. Adel SA. Genotoxicity assessment of a natural anti-cancer compound zerumbone on CHO cell lines. Int J Cancer Res 2012;8:119-29. 